\section{Seed Source and Quality Influence Germination in Purple Coneflower [Echinacea purpurea (L.) Moench.]}

\author{
N. Wartidiningsih and R.L. Geneve \\ Department of Horticulture and Landscape Architecture, University of \\ Kentucky, Lexington, KY 40546
}

Additional index words. seed development, seed size, inflorescence position, light, temperature

\begin{abstract}
Six seed lots of purple coneflower were purchased from four commercial seed sources and evaluated for germination in either light or darkness in combination with two temperature regimes (constant $27 \mathrm{C}$ vs. alternating $30 \mathrm{C}$ for 8 hours and $20 \mathrm{C}$ for 16 hours). Seed lot differences accounted for the majority of variation, with two seed lots exhibiting high $(81 \%$ to $91 \%)$ germination and the remaining seed lots having $39 \%$ to $66 \%$ germination. There was no effect of light on germination, regardless of the seed lot. However, alternating temperatures improved germination in one of the low-germination seed lots. Seed size and inflorescence position did not affect seed germination. Seed harvested at physiological maturity (maximum seed dry weight), but before drying had occurred, had a higher germination percentage than seeds harvested after desiccation, and they maintained a higher germination percentage even after 1 year in storage.
\end{abstract}

Purple coneflower is one of nine Echinacea species that are native to North America in the Asteraceae family. The species is commonly used for wildflower establishment, perennial gardens, and as a cut flower. In addition, root extracts from Echinacea species have antibiotic and antiviral effects and may stimulate the immune system (Kindscher, 1988).

Greenhouse transplants of purple coneflower are started from seeds sown in plug or cell packs. Plants used for drug extraction are field-grown, with the highest root yields produced from transplants (Smith-Jochum and Albrecht, 1987). Economic production of perennial crops requires high-quality seed with rapid, synchronous germination. However, field emergence of direct-seeded purple coneflower has been erratic and generally poor (Smith-Jochum and Albrecht, 1987), and greenhouse germination of purple coneflower has been inconsistent (Finnerty and Zajicek, 1992; Samfield et al., 1991).

The objectives of this study were to determine the conditions for seed testing in purple coneflower and to determine if the variable seed germination of purple coneflower was related to seed size, seed maturity, or inflorescence position of the harvested seed.

\section{Materials and Methods}

Petri dish germination tests were conducted using six seed lots of purple coneflower pur-

Received for publication 4 Feb. 1994. Accepted for publication 11 July 1994. Paper no. 91-10-176 of the Kentucky Agricultural Experiment Station. We thank S.T. Kester and Pam Compton for their technical assistance in the preparation of this manuscript. The research was partially funded through a grant from the Association of Official Seed Analysts. The cost of publishing this paper was defrayed in part by the payment of page charges. Under postal regulations, this paper therefore must be hereby marked adver tisement solely to indicate this fact. chased from four seed companies. These included two seed lots of common purple coneflower (P1 and P2); two seed lots of 'Bright Star' (B1 and B2); one seed lot of 'White Swan' (WS); and one seed lot of 'Bravado' $(\mathrm{Br})$. All seed packages indicated the current year's date and minimum germination as $>90 \%$. Seed packages were stored at $4 \mathrm{C}$ following purchase. Seeds also were collected from openpollinated, 1-year-old plants of purple coneflower grown at the Univ. of Kentucky campus for experiments evaluating the effects of inflorescence position and seed maturation on germination.

Germination was evaluated using 25 seeds placed in $100 \times 15-\mathrm{mm}$ petri dishes containing two pieces of Whatman \#1 filter paper and 4 $\mathrm{ml}$ autoclaved deionized water. Petri dishes were sealed with parafilm and placed in a dark incubator at $27 \mathrm{C}$, except for the experiments comparing the effects of temperature and light on germination. Each treatment (petri dish) was replicated four times. Germination percentage (radicle emergence) was determined after 3 and 10 days [Association of Official Seed Analysts (AOSA), 1986]. In general, germination was complete by 10 days

Seed viability was estimated using a tetrazolium test (Grabe, 1970). Fifty seeds from each seed lot were imbibed in water for 18 to $20 \mathrm{~h}$. The seeds were bisected longitudinally with a razor blade, and one-half of each seed was placed into a petri dish containing $25 \mathrm{ml}$ of $1 \%(\mathrm{w} / \mathrm{v})$ tetrazolium chloride solution. Halfseeds were incubated in a dark chamber at $30 \mathrm{C}$ for $2 \mathrm{~h}$, then the tetrazolium solution was replaced with $25 \mathrm{ml}$ of water. Bisected seeds were examined using a magnifying glass to determine viable or nonviable seed according to the Tetrazolium Testing Handbook guidelines (Grabe, 1970).

The interaction between light and temperature on germination was determined for all seed lots. Germination tests were evaluated for seeds held either in continuous light or darkness at either constant $27 \mathrm{C}$ or alternating cycles at $8 / 16 \mathrm{~h}$ of $30 / 20 \mathrm{C}$, respectively. Coolwhite fluorescent lamps provided photosynthetically active radiation at $\approx 40 \mu \mathrm{mol} \cdot \mathrm{m}^{-2} \cdot \mathrm{s}^{-1}$. Seeds from all seed lots also were separated into two groups according to fresh weight ( $\leq 4$ $\mathrm{mg}=$ small, $>4 \mathrm{mg}=$ large) to determine the effect of seed size on germination. Germination percentage was determined under standard germination conditions (darkness, 27C).

The inflorescences of purple coneflower open sequentially, with the primary inflorescence being the uppermost and largest and lower inflorescences being sequentially smaller. Seeds from the primary, secondary, tertiary, and quaternary inflorescences were harvested when each seed-head was dry, but before the seed-head had shattered. Seed fresh and dry weights (following $48 \mathrm{~h}$ at 50C) were determined for seed harvested from each inflorescence position. Germination of freshly harvested seeds and seeds stored for 1 year [25C, $20 \%$ to $40 \%$ relative humidity $(\mathrm{RH})$ ] were determined.

Seed were harvested at three stages of maturation according to the color and condition of the outer ray florets and seed fresh and dry weights. The three stages were characterized by percent seed moisture content. Germination of these seeds was tested immediately after seed harvest and after 7, 21, and 365 days of storage in brown paper bags in darkness under ambient laboratory conditions (25C, $20 \%$ to $40 \% \mathrm{RH}$ ).

Each experiment was a completely randomized design. Germination percentages were normalized by transformation $(\arcsin \cdot \sqrt{\%})$ for statistical evaluation. The least significant difference (LSD) test was used to compare treatment means, where appropriate.

\section{Results and Discussion}

Seed lots P1 and B1 had higher germination percentages than the other four seed lots after 10 days, a trend that was consistent for each light or temperature treatment, except for seed lot B2, where alternating temperature improved germination (Table 1). The lower germination percentage of seed lots $\mathrm{P} 2, \mathrm{~B} 2$, $\mathrm{Br}$, and WS could not be attributed to low seed viability since the tetrazolium test revealed $82 \%, 74 \%, 84 \%, 76 \%, 76 \%$, and $78 \%$ viability for seed lots P1, P2, B1, B2, WS, and Br, respectively. Alternatively, the lower germination might be the result of dormant or lowvigor seeds within a seed lot. Chilling stratification to relieve dormancy has been a suggested treatment for improving germination in purple coneflower (Hemmerly, 1976; Pinnell et al., 1985). However, high germination percentages in P1 and B1 indicated that these seed lots were not dormant (Table 1).

Light was not required for germination in either high- or low-germination purple coneflower seed lots (Table 1). Inclusion of light during seed testing, however, did not reduce germination percentage. Light has been recommended for enhanced germination of purple coneflower (Foster, 1985; Pinnell et al., 1985). 
Table 1. Effect of light and temperature on germination percentage of six seed lots of purple coneflower after 10 days.

\begin{tabular}{|c|c|c|c|c|c|c|c|}
\hline Light & $\begin{array}{l}\text { Temp } \\
\text { regime }\end{array}$ & \multicolumn{6}{|c|}{ Seed $\operatorname{lot}^{\mathrm{y}}$} \\
\hline regime & $\left({ }^{\circ} \mathrm{C}\right)$ & $\mathrm{P} 1$ & $\mathrm{P} 2$ & B1 & B2 & WS & $\mathrm{Br}$ \\
\hline & & \multicolumn{6}{|c|}{ Germination (\%) } \\
\hline Dark & 27 & 88 & 51 & 88 & 46 & 54 & 58 \\
\hline & $30 / 20$ & 90 & 53 & 82 & 58 & 57 & 53 \\
\hline Light & 27 & 91 & 66 & 87 & 39 & 47 & 54 \\
\hline & $30 / 20$ & 86 & 56 & 81 & 64 & 40 & 58 \\
\hline \multicolumn{8}{|l|}{$\begin{array}{l}\text { F test } \\
\text { significances }\end{array}$} \\
\hline Light regime (L) & & NS & NS & NS & NS & NS & NS \\
\hline Temperature & & & & & & & \\
\hline regime $(\mathrm{T})$ & & NS & NS & * & $* *$ & NS & NS \\
\hline $\mathrm{L} \times \mathrm{T}$ & & NS & NS & NS & NS & NS & NS \\
\hline
\end{tabular}

${ }^{\mathrm{z}}$ Continuous 27 or $30 \mathrm{C}$ for $8 \mathrm{~h}$ alternating with $20 \mathrm{C}$ for $16 \mathrm{~h}$.

yP1, P2 = common purple coneflower; B1, B2 = 'Bravado'; WS = 'White Swan'; Br = 'Brightstar'.

Ns, *, *** Nonsignificant or significant at $P \leq 0.05$ or 0.01 , respectively.

Table 2. Seed fresh and dry weights, percentage of viability via tetrazolium (TZ) test, and germination percentage after 3 and 10 days (27C, darkness) of purple coneflower as influenced by inflorescence position and seed storage (25C, $20 \%$ to $40 \%$ relative humidity).

\begin{tabular}{|c|c|c|c|c|c|c|c|}
\hline \multirow{3}{*}{$\begin{array}{l}\text { Inflorescence } \\
\text { position }\end{array}$} & \multirow{3}{*}{$\begin{array}{l}\text { Initial } \\
\text { viability } \\
(\%)\end{array}$} & \multirow{2}{*}{\multicolumn{2}{|c|}{$\begin{array}{c}\text { Seed } \\
\text { wt (mg) }\end{array}$}} & \multicolumn{4}{|c|}{ Germination after 3 or 10 days (\%) } \\
\hline & & & & \multicolumn{2}{|c|}{ Without storage } & \multicolumn{2}{|c|}{$\begin{array}{c}\text { After } 1 \\
\text { year storage }\end{array}$} \\
\hline & & Fresh & Dry & 3 & 10 & 3 & 10 \\
\hline Primary & 82 & $4.51 \mathrm{a}^{2}$ & $4.05 \mathrm{a}$ & $36 \mathrm{a}$ & $67 \mathrm{a}$ & $29 a$ & $65 \mathrm{a}$ \\
\hline Secondary & 86 & $4.34 \mathrm{a}$ & $3.89 \mathrm{a}$ & $27 \mathrm{~b}$ & $60 \mathrm{~b}$ & $24 \mathrm{~b}$ & $53 \mathrm{~b}$ \\
\hline Tertiary & 84 & $3.73 \mathrm{~b}$ & $3.30 \mathrm{~b}$ & $27 \mathrm{~b}$ & $57 \mathrm{~b}$ & $28 \mathrm{a}$ & $68 \mathrm{a}$ \\
\hline Quaternary & 92 & $3.40 \mathrm{c}$ & $3.03 \mathrm{~b}$ & $27 \mathrm{~b}$ & $65 \mathrm{a}$ & $31 \mathrm{a}$ & $55 \mathrm{~b}$ \\
\hline
\end{tabular}

${ }^{2}$ Mean separation within a column by LSD $(P \leq 0.05)$ using transformed data.

Smith-Jochum and Albrecht (1987) attributed improved germination of uncovered seeds on the surface of the growth medium to increased exposure to light; however, other factors that were not controlled in their study could have affected germination. Currently, AOSA rules (1986) for testing purple coneflower seed include light and alternating temperature for germination. The results from this study generally support the AOSA rules for seed testing in purple coneflower, although seeds germinated equally well in light or darkness (Table 1).

Regardless of seed lot, seed weight had no effect on germination (data not presented). Hemmerly (1976) reported that small seeds (2.0 to $3.9 \mathrm{mg}$ ) of purple coneflower germinated as well as large seeds ( 4.0 to $5.9 \mathrm{mg}$ ) after 10 weeks of stratification at 5C. Thus, seed size was not responsible for the poor germination of seed lots P2, B2, WS, or Br. In other species, the impact of seed size on germination has not been consistent.

Seeds from primary and secondary inflorescences had higher fresh and dry weights than those from tertiary and quaternary inflorescences (Table 2). However, germination percentage was not related consistently to seed weight or inflorescence position in recently harvested or 1-year-old seeds (Table 2). These results reinforce the observation that seed weight does not affect germination and suggest that inflorescence position in purple coneflower plays a minor role in affecting seed germination.

After physiological maturity (maximum seed dry weight), seeds were allowed to dry to $24.5 \%, 15.2 \%$, and $11.6 \%$ moisture before harvest. Seed germination percentage generally decreased as seed moisture decreased at time of harvest (Table 3). These results are consistent with those for soybean (Glycine max Merr.) (Miles et al., 1988), and suggest that seeds have their highest germination potential and vigor at physiological maturity, with seed deterioration beginning upon desiccation. Seed germination percentage decreased quadratically with increasing storage from 7 to 365 days, but the decrease was more pronounced for high-moisture (24.5\% and $15.2 \%$ moisture) seeds than for the driest $(11.6 \%$ moisture) seeds (Table 3). Since seeds for this experiment were stored at $20 \%$ to $40 \% \mathrm{RH}$ and $25 \mathrm{C}$, some seed deterioration in storage was expected.

These results indicated that the stage of seed maturity and possibly seed storage conditions could explain some of the variation in germination observed between seed lots in our study. However, the efficacy of chilling stratification for seeds of purple coneflower
Table 3. Germination percentage after 10 days (27C, darkness) of physiologically mature purple coneflower seeds harvested at three moisture contents and stored at $25 \mathrm{C}$ and $40 \%$ to $50 \%$ relative humidity.

\begin{tabular}{|c|c|c|c|c|}
\hline \multirow{3}{*}{$\begin{array}{l}\text { Seed } \\
\text { moisture } \\
(\%)\end{array}$} & \multicolumn{4}{|c|}{ Germination $(\%)$} \\
\hline & \multicolumn{4}{|c|}{ Days in storage following harvest } \\
\hline & 0 & 7 & 21 & 365 \\
\hline $24.5 \mathrm{a}^{2}$ & $98 \mathrm{a}$ & $90 \mathrm{a}$ & $75 \mathrm{a}$ & $68 \mathrm{a}$ \\
\hline $15.2 \mathrm{~b}$ & $94 \mathrm{~b}$ & $81 \mathrm{~b}$ & $70 \mathrm{a}$ & $62 \mathrm{~b}$ \\
\hline $11.6 \mathrm{c}$ & $68 \mathrm{~b}$ & $64 \mathrm{c}$ & $61 \mathrm{~b}$ & $57 \mathrm{c}$ \\
\hline \multicolumn{5}{|c|}{ F test significance } \\
\hline \multicolumn{2}{|c|}{ Seed moisture $(\mathrm{M})$} & $\frac{\text { F value }}{121.7}$ & & $\frac{f i c a n c e}{\text { *** }}$ \\
\hline \multicolumn{2}{|c|}{ Storage time $(\mathrm{T})$} & 96.7 & & $* *$ \\
\hline \multicolumn{2}{|c|}{$\mathrm{T}$ linear } & & & NS \\
\hline \multicolumn{2}{|c|}{ T quadratic } & & & ** \\
\hline \multicolumn{2}{|c|}{$\mathrm{M} \times \mathrm{T}$} & 21.0 & & ** \\
\hline \multirow{2}{*}{\multicolumn{2}{|c|}{$\mathrm{M} \times \mathrm{T}$ linear }} & & & NS \\
\hline & $\mathrm{M} \times \mathrm{T}$ quadratic & & & *** \\
\hline
\end{tabular}

${ }^{2}$ Means within a column followed by the same letter were not significantly different by LSD $(P \leq 0.05)$ using transformed data.

ss, ${ }^{* *}$ Nonsignificant or significant at $P \leq 0.01$, respectively.

(Hemmerly, 1976; Pinnell et al., 1985) suggests that seed dormancy may contribute to the variation in germination observed between seed lots.

\section{Literature Cited}

Association of Official Seed Analysts. 1986. Rules for seed testing. J. Seed Technol. 13:1-126.

Finnerty, T. and J.M. Zajicek. 1992. Effects of seed priming on plug production of Coreopsis lanceolata and Echinacea purpurea. J. Environ. Hort. 10:129-132.

Foster, S. 1985. Echinaceas, the purple coneflowers. Amer. Hort. 64:14-17.

Grabe, D.F. (ed.). 1970. Tetrazolium testing handbook for agricultural seeds. Handbook on seed testing. Assn. Official Seed Analysts Contrib. no. 29:1-62.

Hemmerly, T.E. 1976. Life cycle strategy of a highly endemic cedar glade species: Echinacea tennesseensis (Compositae). PhD Diss., Vanderbilt Univ., Nashville.

Kindscher, K. 1989. Ethnobotany of purple coneflower (Echinacea augustifolia, Asteraceae) and other Echinacea species. Econ. Bot. 43:498507.

Miles, D.F., Jr., D.M. Tekrony, and D.B. Egley. 1988. Changes in viability, germination, and respiration of freshly harvested soybean seed. Crop Sci. 28:700-704.

Pinnell, M.M., A.M. Armitage, and D. Seaborn. 1985. Germination needs of common perennial seed. Agr. Expt. Sta. Res. Bul. 331, Univ. of Georgia, Athens.

Samfield, D.M., J. Zajicek, and G.B. Cobb. 1991. Rate and uniformity of herbaceous perennial seed germination and emergence as affected by priming. J. Amer. Soc. Hort. Sci. 116:10-13.

Smith-Jochum, C.C. and M.L. Albrecht. 1987. Field establishment of three Echinacea species for commercial production. Acta Hort. 208:115119 . 